DOI: https://doi.org/10.31933/jimt.v2i2

Received: 5 November 2020, Revised: 25 November 2020, Publish: 17 Desember 2020

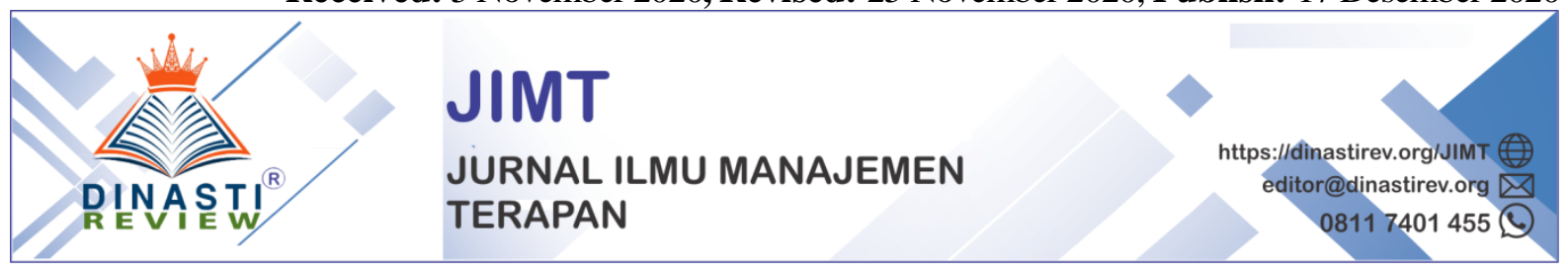

\title{
DETERMINAN KUALITAS LAPORAN KEUANGAN DAN KINERJA KEUANGAN: BUDAYA KERJA DAN KOMPETENSI (STUDI KASUS : BADAN PUSAT STATISTIK WILAYAH SUMATERA UTARA)
}

\section{Kristina Ginting}

Pasca Sarjana Universitas Terbuka, Indonesia, gtkristine@ gmail.com

\section{Corresponding Author: First Author}

Abstrak: Laporan Keuangan dan Kinerja Keuangan merupakan hasil pelaksanaan dan pemanfaatan anggaran yang dialokasikan pada sebuah instansi pemerintah, kualitas laporan keuangan dan keberhasilan pencapaian kinerja keuangam dapat dipengaruhi oleh budaya kerja sebuah intansi,di Badan Pusat Statistik budaya kerja identik dengan reformasi birokrasi dengan nilai inti PIA (Profesional, Integritas, Amanah). Kualitas laporan keuangan dan kinerja keuangan juga dipengaruhi oleh kompetensi pegawai atau staf yang berhubungan langsung dalam kegiatan perencanaan, pelaksanaan, pelaporan keuangan. Kompetensi seluruh pegawai juga berhubungan langsung dengan pencapaian kinerja keuangan sebuah intansi.

Kata kunci : laporan keuangan, kinerja, budaya kerja, kompetensi pegawai

\section{PENDAHULUAN}

\section{Latar Belakang Masalah}

Intansi pemerintah merupakan lembaga baik dalam bentuk Kementerian ataupun Lembaga non Kementerian berupa Badan, Komisi, dan Dewan, merupakan perpajangan tangan pemerintah dalam menjalankan roda pemerintahan. Intansi Pemerintah diberikan amanah untuk membantu pemerintah dalam melaksanakan pembangunan dan memberikan layanan sosial kepada masayarakat dengan tujuan untuk mencapai tujuan bernegara yaitu masyarakat sejahtera adil dan makmur. Dalam menjalankan tugas dan fungsinya, intansi pemerintah mendapatkan alokasi anggaran, kemudian menggunakan anggaran tersebut, melaporkan dan mempertanggungjawabkan dalam bentuk laporan keuangan. Melalui laporan keuangan dapat dilihat kinerja keuangan seperti rasio likuiditas, rasio solvabilitas, rasio pertumbuhan dan sumber daya yang digunakan. Kinerja instansi pemerintah tidak dapat diukur dari satu indikator 
saja, tidak ada indikator tunggal yang dapat digunakan untuk menunjukkan tingkat keberhasilan secara komprehensif. Pengukuran kinerja keuangan intansi pemerintah dapat dilakukan melalui pendekatan anggaran, laporan keuangan, performa audit dan penerapan reformasi birokrasi.

Dalam perencanaan, pelaksanaan dan pelaporan penggunaan anggaran, masih terdapat beberapa kendala yang sering dihadapi oleh pelaksana anggaran, seperti adanya revisi-revisi alokasi anggaran, adanya hasil audit yang belum memuaskan, adanya revisi-revisi laporan keuangan, penurunan IKPA (indek kumulatif pelaksanaan anggaran) dan dan pencapaian kinerja yang tidak maksimal.

Berdasarkan uraian diatas, penulis tertarik untuk melakukan penelitian tentang pengaruh budaya kerja yang diterapkan dan kompetensi pegawai terhadap perencanaan anggaran, laporan keuangan dan kinerja keuangan pemerintah di Badan Pusat Statistik Wilayah Provinsi Sumatera Utara dengan judul "Determinan Kualitas Laporan Keuangan dan Kinerja: Budaya Kerja dan Kompetensi (Studi kasus : Badan Pusat Statistik Wilayah Provinsi Sumatera Utara)”. Penelitian ini mengambil sampel laporan anggaran, laporan keuangan dan laporan kinerja pada Badan Pusat Statistik Provinsi Sumatera Utara tahun 2019.

\section{Rumusan Masalah}

Bersadarkan uraian pada latar belakang masalah, maka diketahui bahwa perencanaan anggaran, pelaporan keuangan dan kinerja keuangan merupakan bentuk pertanggungjawaban atas pelaksaanaan tugas dan fungsi sebagai instansi pemerintah yang dikaji melalui budaya kerja dan kompetensi pegawai. Untuk mencapai sasaran yang diharapkan maka ditetapkan rumusan masalah dalam penelitian ini antara lain:

1. Apakah Kualitas Laporan keuangan berpengaruh terhadap kinerja keuangan pemerintah?

2. Apakah kinerja keuangan berpengaruh terhadap kualitas laporan keuangan pemerintah?

3. Apakah Budaya Kerja berpengaruh terhadap Kualitas Laporan Keuangan pemerintah?

4. Apakah Budaya Kerja berpengaruh terhadap pencapaian kinerja keuangan pemerintah?

5. Apakah Kompetensi berpengaruh terhadap Kualitas Laporan Keuangan pemerintah?

6. Apakah Kompetensi berpengaruh terhadap Kinerja Keuangan pemerintah?

\section{Tujuan Penelitian}

Penelitian ini dilakukan dengan tujuan yang dapat menjawab pertanyaan pada rumusan masalah yaitu: 
1. Untuk memperoleh bukti empiris terkait pengaruh Laporan keuangan berpengaruh terhadap kinerja keuangan pemerintah.

2. Untuk memperoleh bukti empiris terkait pengaruh Standar Akuntansi Pemerintah berpengaruh terhadap Laporan Keuangan pemerintah.

3. Untuk memperoleh bukti empiris terkait pengaruh Standar Akuntansi Pemerintah berpengaruh terhadap pencapaian kinerja keuangan pemerintah.

4. Untuk memperoleh bukti empiris Database Managemen Sistem berpengaruh terhadap Laporan Keuangan pemerintah.

5. Untuk memperoleh bukti empiris terkait pengaruh Database Managemen Sistem berpengaruh terhadap Kinerja Keuangan pemerintah.

6. Untuk memperoleh bukti empiris terkait pengaruh Apakah Standar Akuntansi berpengaruh terhadap Database Managemen sistem.

\section{KAJIAN PUSTAKA}

\section{Laporan Keuangan}

Laporan keuangan adalah laporan yang menunjukkan kondisi keuangan perusahaan pada saat ini atau dalam suatu periode tertentu, menggambarkan kondisi keuangan perusahaan selama periode tertentu yang dapat berguna pihak-pihak yang membutuhkan laporan keuangan tersebut (Kasmir 2014:7)

Laporan keuangan pemerintah adalah laporan keuangan menurut Peraturan Pemerintah Nomor 71 Tahun 2010 yang terstruktur mengenai posisi keuangan dan transaksi-transaksi yang dilakukan oleh suatu entitas pelaporan"(Harahap 2008: 201),

Laporan Keuangan yang berkualitas merupakan laporan keuangan yang harus memliki karakteristik relevan, andal, dapat dibandingkan dan dapat dipahami, disajikan oleh suatu entitas sebagai bentuk pertanggungjawaban pada periode laporan tertentu. Laporan keuangan relavan apabila informasi disajikan pada laporan keuangan dapat membantu mengevaluasi permasalahan dimasa yang lalu, mampu memberikan gambaran akan masa yang akan datang dan dapat dipakai dalam pengambilan keputusan. Laporan keuangan andal pada saat laporan keangan disajikan sesuai dengan keadaan sesungguhnya, tidak memberikan informasi yang sesat, dan bersifat independen. Karekter laporan keuangan juga harus dapat dibandingkan antar periode pelaporan pada suatu entitas, bahkan bisa dibandingkan antar entintas. Laporan keuangan juga harus dapat dipahami oleh setiap pengguna dan dapat dinyatakan melalui opini 
pada saat review atau pemeriksaan. Laporan keuangan pemerintah juga harus mengikuti ketentuan yang telah ditetapkan sesuai Standar Akuntansi Pemerintah (SAP). Dalam penentuan kualitas laporan keuangan pemerintah harus mengacu kepada peraturan-peraturan yang telah disusun dan ditetapkan oleh pemerintah dan menteri keuangan yang juga termuat dalam Standar Akuntansi Pemerintah.

\section{Kinerja Keuangan}

Laporan Kinerja keuangan disusun sebagai bentuk akuntabilitas terhadap pelaksanaan tugas dan fungsi atas penggunaan anggaran. Laporan Kinerja juga merupakan wujud pertanggungjawaban atas kinerja pencapaian visi dan misi yang telah ditetapkan.

Pengertian kinerja keuangan dapat dipahami melalui beberapa pendapat para ahli, antara lain dapat dilihat pada uraian berikut:

a. Fahmi (2012:2) Kinerja keuangan adalah gambaran tentang keberhasilan perusahaan berupa hasil yang telah dicapai berkat berbagai aktivitas yang telah dilakukan. Kinerja keuangan merupakan suatu analisis untuk menilai sejauh mana suatu perusahaan telah melaksanakan aktivitas sesuai aturan-aturan pelaksanaan keuangann.

b. Mulyadi (2007:2) Kinerja keuangan adalah penentuan efektifitas operasional suatu organisasi dan karyawan secara periodik berdasarkan sasaran, standar dan kriteria yang telah ditetapkan.

c. IAI (Ikatan Akuntan Indonesia) Kinerja keuangan adalah kemampuan perusahaan dalam mengelola dan mengendalikan sumber daya yang dimiliki.

d. Rudianto (2013:189) mengemukakan bahwa Kinerja keuangan adalah hasil atau prestasi yang telah dicapai oleh manajemen perusahaan dalam mengelola aset perusahaan secara efektif selama periode tertentu. Kinerja keuangan sangat dibutuhkan oleh perusahaan untuk mengetahui dan mengevaluasi tingkat keberhasilan perusahaan berdasarkan aktivitas keuangan yang telah dilaksanakan.

Kinerja keuangan pemerintah merupakan kualitas pencapaian dari suatu hasil kerja dibidang keuangan yang terdiri dari perencanaan, pelaksanaan dan pertanggungjawaban penerimaan dan belanja negara dengan menggunakan indikator keuangan yang ditetapkan melalui suatu peraturan/kebijakan atau ketentuan perundang-undangan selama satu periode anggaran. Instruksi Presiden Republik Indonesia Nomor 7 Tahun 1999 Tentang Akuntabilitas Kinerja Instansi Pemerintah juga menyatakan bahwa dalam rangka lebih meningkatkan pelaksanaan pemerintahan yang lebih berdaya guna, berhasil guna dan bertanggung jawab, 
maka pelaporan akuntabilitas kinerja instansi pemerintah dapat dijadikan dasar untuk mengetahui kemampuan instansi pemerintah dalam pencapaian visi, misi, dan tujuan organisasi sehingga dapat dilakukan perbaikan kinerja yang berkesinambungan. Pelaporan akuntabilitas kinerja tersebut dilaksanakan melalui penyusunan Laporan Kinerja.

\section{Budaya Kerja}

Budaya kerja pada setiap intansi pasti memiliki karakter individu masing-masing, namun karakter yang berbeda-beda tersebut diarahkan untuk satu pandangan atau satu tujuan, melalui penyatuan cara pandang dapat menumbuhkan keyakinan yang berdasarkan pada nilainilai yang di yakini para pegawai untuk mewujudkan prestasi kerja. Budaya kerja juga dapat menjadi nilai inti dari setiap program kegiatan yang dilaksanakan oleh suatu intansi, dengan kata lain keberhasilan suatu instansi sangat dipengaruhi oleh budaya kerja.

Pengertian budaya kerja dapat dipahami melalui beberapa pendapat para ahli antara lain:

a. Mangkunegara (2005) mendefinisikan bahwa budaya kerja adalah seperangkat asumsi atau sistem keyakinan, nilai-nilai dan norma yang dikembangkan dalam organisasi yang dijadikan pedoman tingkah laku bagi anggota-anggotanya untuk mengatasi masalah adaptasi eksternal dan integrasi internal.

b. Supriyadi dan Tri Guno, pengertian budaya kerja adalah sebuah falsafah yang berlandaskan pada pandangan hidup sebagai nilai yang menjadi kebiasaaan, sifat dan pendorong yang dibudayakan dalam sebuah kelompok dan tercermin pada sikap menjadi perilaku, cita-cita, pendapat, pandangan serta tindakan yang terwujud sebagai kerja.

c. Nawawi (2003)

budaya kerja adalah kebiasaan yang dijalankan secara berulang oleh para pegawai di dalam suatu organisasi.Terjadinya pelanggaran pada kebiasaan-kebiasaan ini memang tidak akan diberikan sangsi yang tegas tapi para pelaku secara moral telah bersepakat bahwa kebiasaan tersebut merupakan kebiasaan yang harus diikuti dengan maksud agar pelaksanaan pekerjaan dapat mencapai tujuan.

\section{Kompetensi}

Kompetensi merupakan kemampuan atau kecakapan untuk melakukan sesuatu dan dapat mempengaruhi semua aspek dalam suatu organisasi. Suatu Organisasi dapat berjalan dengan baik dan mencapai tujuan yang telah ditetapkan apabila memiliki sumber daya manusia yang berkompetensi yang baik. Namun sebaliknya, tujuan sebuah organisasi tidak akan 
tercapai atau pencapaian kinerja tidak maksimal apabila kompetensi sumber daya manusianya tidak memadai. Pengertian komptensi menerut para ahli dapat dilihat pada uraian berikut:

d. Emron, Yohny, Imas (2017,P.140) kompetensi adalah kemampuan individu untuk melaksanaka suatu pekerjaan dengan benar dan memiliki keunggulan yang didasarkan pada hal-hal yang menyangkut pengetahuan, keahlian dan sikap.

e. Suparno (2012: 27)

Pengertian kompetensi menurut Suparno adalah kecapakan yang memadai untuk melakukan suatu tugas atau sebagai memiliki keterampilan dan kecakapan yang diisyratkan.

f. Stephen Robbin (2007: 38)

Pengertian kompetensi menurut Stephen Robbin adalah kemampuan (ability) atau kapasitas seseorang untuk melakukan berbagai tugas dalam suatu pekerjaan, dimana kemampuan ini ditentukan oleh dua faktor yang kemampuan intelektual dan kemampuan fisik.

Kompetensi juga tidak dapat dipasahkan dari pendidikan formal yang telah ditempuh oleh pegawai/staf dalam suatu instansi atau organisasi pemerintah. Kompetensi sumber daya manusia dalam melaksanakan tugas fungsi akuntansi dapat dilihat dari latar belakang pendidikan, bimbingan teknis terkait keuangan yang pernah diikuti, pelatihan-pelatihan yang pernah diikuti, serta keterampilan pengelolaan keuangan lainnya yang dimiliki. Hal tersebut yang dapat digunakan sebagai indikator untuk mengukur kompetensi pegawai/staf sebagai sumber daya manusia organisasi pemerintah selain pemahaman terhadap peraturan dan standar, kemampuan berinteraksi dengan sistem, kemampuan mengikuti perkembangan inovasi dan teknologi melalui pelatihan dan bimtek, serta pengalaman bekerja.

\section{METODE PENELITIAN}

Metode penelitian artikel ilmiah ini adalah dengan metode kualitatif melalui prariset (keusioner) dan studi literature atau Library Research.

Metode penelitian pada artikel ini juga menggunakan variable-variable yang saling berpengaruh yang terdiri dari dependen dan independen.

a. Variabel dependen

Variabel dependen dalam penelitian ini adalah kualitas laporan keuangan (Y1) dan kinerja keuangan (Y2). Kualitas laporan keuangan dapat dilihat berdasarkan karakteristik yang dimiliki laporan keuangan yang seharusnya sesuaiu dengan Standar Akuntansi Pemerintah. 
Pemahaman tentang karakteristik laporan keuangan yang akuntabel dan dapat dipahami tersebut dapat diperoleh melalui studi leteratur buku Standar Akuntansi Pemerintah dan kumpulan peraturan pemerintah dan kementerian keuangan terkait penyusunan dan pelaporan keuangan.

Karakteristik kualitatif laporan keuangan adalah ukuran-ukuran normatif yang perlu diwujudkan dalam informasi akuntansi sehingga dapat memenuhi tujuannya. Adapun karakteristik kualitatif laporan keuangan yaitu: relevan, andal, dapat dibandingkan, dan dapat dipahami. Karakteristik tersebut yang selanjutnya akan dijadikan sebagai indikator. Instrumen pengukuran dapat dilakukan dengan wawancara sampel yang telah ditetapkan dengan menggunakan skala likert.

Demikian juga halnya dengan variable dependen yang ke dua yaitu kinerja keuangan. Pencapaian kinerja suatu organisasi pemerintah/instansi tidak terlepas dari pecapaian target atau rencana kerja yang telah ditetapkan. Indikator yang dapat diterapkan untuk mengukur kinerja keuangan adalah: capaian output kegiatan, pencapaian realiasai anggran yang sudah ditetapkan, pencapain target rencana stategis yang sudah ditetapkan dan peningkatan kualitas pelayanan ke public atau masyarakat, yang keseluruhan laporannya dapat dilihat melali laporan kinerja tahunan.

b. Variabel Independen

Dalam penelitian ini yang menjadi variable independen adalah Budaya kerja (X1) dan Kompetensi sumber daya manusia (X2). Budaya kerja merupakan unsur utama dalam suatu organisasi pemerintah yang tidak terlepas dari gaya kepemimpinan, komunikasi yang efektif dalam organisasi, latar belakang Pendidikan latar belakang pribadi individu, dan motivasi kerja yang memiliki keterkaitan dengan peningkatan kulitas laporan keuangan. Varibel ke dua (X2) yaitu kompetensi, merupakan kemampuan yang dimiliki sumber daya manusia dalam suatu organisasi pemerintah/instansi untuk mendukung proses pelaksanaan kegiatan mulai dari perencanaan penganggran hingga pada pelaporan dan pertanggungjawaban keuangan.

Data Penelitian ini menggunakan laporan keuangan, laporan kinerja tahun 2019dan hasil kuesioner terhadap sample di BPS Provinsi Sumatra Utara.

c. Populasi dan Sampel

Populasi dalam penelitian ini adalah seluruh pegawai di lingkungan kerja Badan Pusat Statistik Provinsi Sumatera Utara. Kriteria sampel didasarkan pada pihak-pihak yang terkait secara langsung dengan perencanaan, pelaksanaan anggaran, pelaporan keuangan 
dan kinerja. Adapun yang menjadi sampel adalah : Pejabat Pembuat Komitmen, Pejabat Penandatanganan SPM, bendahara Pengeluaran, Bendahara Penerimaan, Kasubbag Keuangan, Kasubbag Program, Kasubbag Umum, dan seluruh staf dibagian ketatausahaan dengan jumlah 20 orang.

d. Model Penelitian

Model kerangka kerja (Frame work) dalam penelitian ini dapat dilihat sebagai berikut:

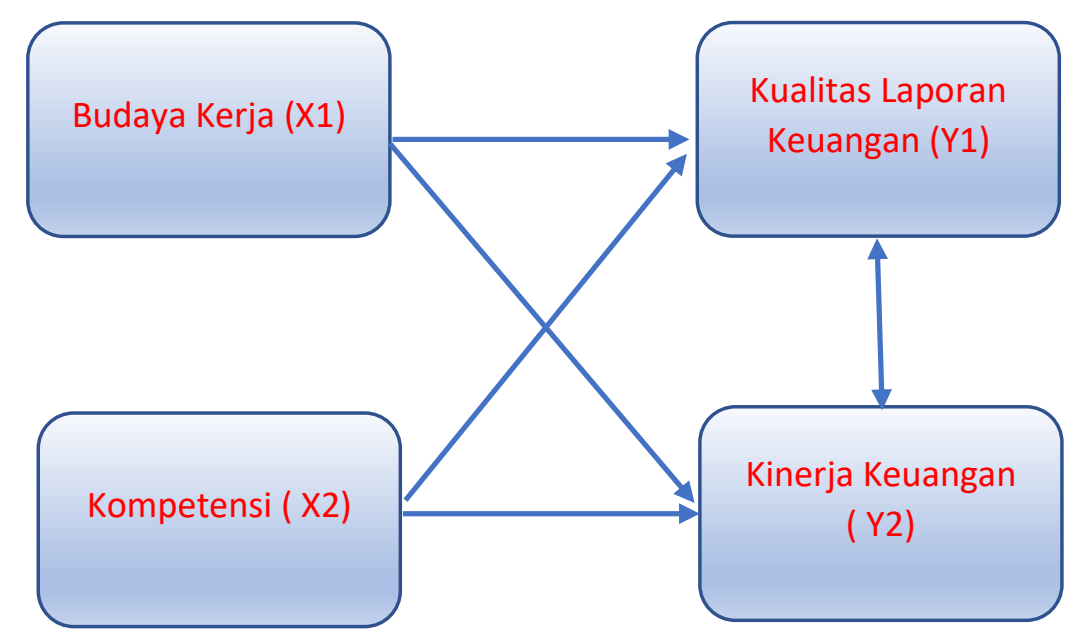

\section{HASIL DAN PEMBAHASAN}

\section{Penjelasan tentang Badan Pusat Statistik}

Gambaran Umum Badan Pusat Statistik

Badan Pusat Statistik adalah Lembaga Pemerintah Non Kementerian yang bertanggung jawab langsung kepada Presiden. Sebelumnya, BPS merupakan Biro Pusat Statistik, yang dibentuk berdasarkan UU Nomor 6 Tahun 1960 tentang Sensus dan UU Nomer 7 Tahun 1960 tentang Statistik. Sebagai pengganti kedua UU tersebut ditetapkan UU Nomor 16 Tahun 1997 tentang Statistik. Berdasarkan UU ini yang ditindaklanjuti dengan peraturan perundangan dibawahnya, secara formal nama Biro Pusat Statistik diganti menjadi Badan Pusat Statistik.Materi yang merupakan muatan baru dalam UU Nomor 16 Tahun 1997, antara lain :

a. Jenis statistik berdasarkan tujuan pemanfaatannya terdiri atas statistik dasar yang sepenuhnya diselenggarakan oleh BPS, statistik sektoral yang dilaksanakan oleh instansi Pemerintah secara mandiri atau bersama dengan BPS, serta statistik khusus yang 
diselenggarakan oleh lembaga, organisasi, perorangan, dan atau unsur masyarakat lainnya secara mandiri atau bersama dengan BPS.

b. Hasil statistik yang diselenggarakan oleh BPS diumumkan dalam Berita Resmi Statistik (BRS) secara teratur dan transparan agar masyarakat dengan mudah mengetahui dan atau mendapatkan data yang diperlukan.

c. Sistem Statistik Nasional yang andal, efektif, dan efisien.

d. Dibentuknya Forum Masyarakat Statistik sebagai wadah untuk menampung aspirasi masyarakat statistik, yang bertugas memberikan saran dan pertimbangan kepada BPS.

Berdasarkan undang-undang yang telah disebutkan di atas, peranan yang harus dijalankan oleh BPS adalah sebagai berikut :

a. Menyediakan kebutuhan data bagi pemerintah dan masyarakat. Data ini didapatkan dari sensus atau survey yang dilakukan sendiri dan juga dari departemen atau lembaga pemerintahan lainnya sebagai data sekunder

b. Membantu kegiatan statistik di kementrian, lembaga pemerintah atau institusi lainnya, dalam membangun sistem perstatistikan nasional.

c. Mengembangkan dan mempromosikan standar teknik dan metodologi statistik, dan menyediakan pelayanan pada bidang pendidikan dan pelatihan statistik.

d. Membangun kerjasama dengan institusi internasional dan negara lain untuk kepentingan perkembangan statistik Indonesia

\section{Visi Misi Badan Pusat Statistik}

Dengan mempertimbangkan capaian kinerja, memperhatikan aspirasi masyarakat, potensi dan permasalahan, serta mewujudkan Visi Presiden dan Wakil Presiden maka visi Badan Pusat Statistik untuk tahun 2020-2024 adalah:

"Penyedia Data Statistik Berkualitas untuk Indonesia Maju"

("Provider of Qualified Statistical Data for Advanced Indonesia")

Dalam visi yang baru tersebut berarti bahwa BPS berperan dalam penyediaan data statistik nasional maupun internasional, untuk menghasilkan statistik yang mempunyai kebenaran akurat dan menggambarkan keadaan yang sebenarnya, dalam rangka mendukung Indonesia Maju.

Dengan visi baru ini, eksistensi BPS sebagai penyedia data dan informasi statistik menjadi semakin penting, karena memegang peran dan pengaruh sentral dalam penyediaan statistik 
berkualitas tidak hanya di Indonesia, melainkan juga di tingkat dunia. Dengan visi tersebut juga, semakin menguatkan peran BPS sebagai pembina data statistik.

Misi BPS dirumuskan dengan memperhatikan fungsi dan kewenangan BPS, visi BPS serta melaksanakan Misi Presiden dan Wakil Presiden yang Ke-1 (Peningkatan Kualitas Manusia Indonesia), Ke-2 (Struktur Ekonomi yang Produktif, Mandiri, dan Berdaya Saing) dan yang Ke-3 Pembangunan yang Merata dan Berkeadilan, dengan uraian sebagai berikut:

a. Menyediakan statistik berkualitas yang berstandar nasional dan internasional

b. Membina K/L/D/I melalui Sistem Statistik Nasional yang berkesinambungan

c. Mewujudkan pelayanan prima di bidang statistik untuk terwujudnya Sistem Statistik Nasional

d. Membangun SDM yang unggul dan adaptif berlandaskan nilai profesionalisme, integritas dan amanah

\section{Reformasi Birokrasi}

Reformasi birokrasi merupakan gambaran budaya kerja yang di terapkan di seluruh Badan Pusat Statitik di Indonesia. Reformasi birokrasi tersebut adalah reformnasi berbasis kinerja, yang mencakup seluruh aspek dalam organisasi Badan Pusat Statistik mulai dari sistem pelayanan publik, sistem pelaksanaan tugas secara global hingga pada pola pikir secara individual insan Badan Pusat Statistik. Reformasi birokrasi memiliki target yang diambil untuk lima tahun kedepan BPS sudah beranjak ke tahapan pemerintah yang berbasis kinerja. Untuk jangka panjang, di tahun 2025 diharapkan pemerintahan sudah beranjak kepada suatu tatanan yang dinamis. Adapun tujuan reformasi birokrasi di Badan Pusat Statistik adalah sebagai berikut:

a. Pemerintahan yang efektif, efisien dan ekonomis

b. Focus pada outcome

c. Penerapan e-performace

d. Setiap individu memeiliki kontribusi yang jelas dalam organisasi

Sasaran yang telah ditetapkan dalam reformasi birokrasi di Badan Pusat Statitik (BPS) antara lain:
a. BPS yang bersih dan akuntable
b. BPS yang efektif dan efisien
c. BPS yang memiliki pelayanan publik yang berkualitas
d. BPS yang menghasilkan data statistic yang berkualitas 
Area perubahan yang telah ditetapkan untuk mencapai tujuan dan sasaran reformasi birokrasi di BPS adalah dengan melakukan:

a. Manajemen perubahan

Mengubah sistem, pola pikir dan budaya kerja menjadi lebih baik yang sesuai dengan tujuan dan sasaran reformasi birokrasi

b. Penataan dan penguatan organisasi

Menigkatkan efesiensi dan efektifitas organisasi Badan Pusat Statistik secara proforsional sesuai kebutuhan sehingga organisasi BPS menjadi tepat fungsi dan tepat ukuran.

c. Penataan peraturan perundang-undangan

Meningkatkan efektifitas pengelolaan peraturan perundang-undangan yang diterbitkan oleh BPS

d. Penataan Sumber daya manusia

Meningkatkan profesionalisme SDM pegawai BPS yang didukung oleh sistem rekrutmen, transparan, serta memperoleh gaji dan bentuk jaminan kesejahteraan yang sepadan.

e. Penataan Tata laksana

Meningkatkan efesiensi dan efektifitas sistem, proses dan prosedur kerja

f. Penguatan pengawasan

Mewujudkan pemerintahan yang bersih dan bebas KKN seperti tertulis pada undangundang nomor 28 tahun 1999

g. Penguatan akuntabilitas kerja

Meningkatkan kapasitas dan kapabilitas kinerja birokrasi BPS.

h. Peningkatan kualitas pelayanan public

Memberikan pelayanan yang lebih cepat, lebih murah dan lebih berkualitas.

\section{Pengaruh Kualitas Laporan Keuangan terhadap kinerja keuangan pemerintah}

Laporan keuangan yang baik harus sesuai dengan sistem akuntansi pemerintah pusat yang dilandasi oleh peraturan perundang-undangan. Beberapa peraturan yang melandasi pelaksanaan akuntansi di lingkungan pemerintah antara lain:

a. Undang-undang no. 17 tahun 2003 tentang keuangan Negara

b. Undang-undang no. 1 tahun 2004 tentang perbendaharaan Negara

Sistem akuntansi yang di terapkan oleh Badan Pusat Statistik Provinsi Sumatera Utara merupakan sistem akuntansi pemerintahan pusat yang memiliki ciri-ciri sebagai berikut: 
a. berbasis akrual, untuk pengakuan asset, kewajiban, ekuitas dalam neraca, dan juga kas pada pengakuan pendapatan, belanja dan pengembalian belanja dalam Laporan realisasi anggaran.

b. sistem pembukuan yang berpasangan (memiliki persamaan dasar akuntansi) yaitu asset $=$ ekitas +kewajiban

c. mengelola dana tunggal yang mempertanggungjawabkan pendapatan dan belanja pemerintah sebagai kesatuan yang tunggal

d. disentalisasi pelaksanaan akuntansi yang dilaksanakan secara berjenjang mulai oleh unit akuntansi BPS RI sampai dengan unit terendah di daerah.

e. Memiliki bagan akun standar yang ditetapkan oleh menteri keuangan.

f. Sesuai dengan Standar akuntansi pemerintah, dalam melakukan pengakuan, penilaian, pencatatan, penyajian dan pengungkapan terhadap transaksi keuangan dalam rangka perencanaan, pelaksanaan anggran, pertanggungjawaban, akuntansi dan pelaporan keuangan.

Keseluruhan ciri tersebut telah dapat dilihat pada laporan keuangan BPS Provinsi Sumatera Utara periode pelaporan tahunan 2019. Kualitas laporan keuangan BPS Provinsi Sumatera Utara tahun 2019 tersebut dapat dikatakan sudah cukup baik karena telah sesuai juga dengan Standar Akuntansi Pemerintahan.

Berdasarkan hasil survey terhadap sampel dan studi literature yang dilakukan melalui buku laporan keuangan tahun 2019 maka dapat disimpulkan bahwa kualitas laporan keuangan BPS Provinsi Sumatera Utara telah sesuai dengan standar, dapat dipahami dan telah memberikan informasi pelaksanaan anggaran dengan baik. Berdasarkan survei dan informasi dari buku laporan keuangan, kualitas laporan keuangan BPS Provinsi Sumatera Utara juga berhubungan terhadap kinerja keuangan yang dapat dilihat dari laporan pelaksanaan anggaran, laporan realisasi, laporan capaian output kegiatan yang merupakan informasi yang disajikan dalam laporan keuangan juga merupakan bagian dari laporan kinerja. Pelaksanaan anggaran mulai dari perencanaan sampai pada pertanggungjawaban pelaksanaan anggaran merupakan sasaran kinerja BPS Provinsi Sumatera Utara yang ditargetkan dengan pencapaian tujuan visi dan misi BPS Provinsi Sumatera Utara. Semakin tinggi pencapaian target pelaksanaan anggaran maka semakin tinggi juga capaian kinerja di BPS Provinsi Sumatera Utara.

\section{Pengaruh Kinerja terhadap kualitas laporan keuangan pemerintah}


Secara umum kinerja BPS Provinsi Sumatera Utara tahun 2019 dapat dikatakan cukup baik, hal ini dapat dilihat dari rata-rata capaian kinerja tujuan dan sasaran strategis yang masingmasing sebesar 96,41 persen dan sebesar 123,03 persen. BPS Provinsi Sumatera Utara selalu berupaya untuk menghasilkan data yang berkualitas, namun pada tahun 2019 capaian kinerja indikator tujuan terhadap Renstra 2015-2019 tersebut pengalami penurunan namun tidak terlalu timpang sebesar 104,01 persen pada tahun 2018 menjadi sebesar 99,84 persen pada tahun 2019. Demikian juga keinginan untuk meningkatkan pelayanan prima atas hasil kegiatan statistik, juga tercermin dari semakin meningkatnya kepuasan konsumen atas pelayanan data BPS. Peningkatan birokrasi yang akuntabel juga didukung dengan kegiatankegiatan yang bersifat membangun Sumber Daya Manusia pada pegawai BPS Provinsi Sumatera Utara serta meningkatkan kinerja bukan hanya yang bersifat teknis, tetapi juga yang bersifat non teknis seperti pada bidang administrasi.

Dalam rangka mendukung tercapainya tujuan dari program dan kegiatan yang diusulkan, pada TA 2019 BPS Provinsi Sumatera Utara mendapatkan pagu sebesar Rp.46.782.182.000 dengan realisasi sebesar Rp. 44.164.644.829,-. Jika dibandingkan dengan capaian kinerja tujuan maupun sasaran strategis dapat dikatakan BPS telah melakukan efisiensi penggunaan anggaran dengan penyerapan anggaran sebesar 94,40 persen. Pencapaian kinerja dibidang administrasi tersebut tentu memberikan pengaruh langsung terhadap pelaporan keuangan BPS Provinsi Sumatera Utara. Dari sisi sumber daya manusia, kinerja juga sangat mempengaruhi kualitas laporan keuangan, artinya sumber daya manusia yang merupakan pegawai dalam Badan Pusat Statistik harus memiliki sinergi dalam pelaksanaan tugas dan fungsinya, yang dalam hal ini pegawai yang terkait dengan proses pelaksanaan anggaran dan pegawai di bagian subbagian keuangan yang bertugas dalam penyusunan laporan keuangan.

\section{Pengaruh Budaya Kerja terhadap Kualitas Laporan Keuangan pemerintah}

Seperti yang telah dikemukan sebelumnya bahwa budaya kerja di BPS Provinsi Sumatera Utara dicerminkan melalui pencapain Reformasi Birokrasi, maka dapat disimpulkan bahwa budaya kerja memiliki pengaruh terhadap kualitas laporan keuangan. Budaya kerja melalui pencapaian reformasi birokrasi telah menetapkan suatu agenda perubahan untuk mewujudkan BPS yang bersih dan akuntabel. dalam hal ini BPS sebagai perpanjangan tangan pemerintah harus menjaga momentum pengelolaan ekonomi terutama pada berbagai proyek-proyek dan kebijakaan pemerintah yang penting dengan menjaga akuntabilitas dan 
konsistensi. Hal tersebut dapat dilihat melalui pencapaian Predikat WTP yang merupakan kewajiban bagi seluruh Kementerian/Lembaga dan instansi pemerintah lainnya dalam menjaga akuntabilitas pengelolaan keuangan negara. Opini WTP diberikan jika tidak ditemukan kesalahan secara keseluruhan dari laporan keuangan. BPS berhasil mempertahankan predikat WTP pada tahun 2019. Dalam pengelolaan Barang Milik Negara (BMN), BPS juga menerima penghargaan sebagai juara ke-2 instansi pemerintah kategori kualitas pelaporan BMN untuk Kementerian lembaga yang memiliki Satuan kerja di atas 100. Hal tersebut menandakan bahwa kepatuhan BPS dalam menyajikan laporan keuangan sesuai dengan standar akuntansi yang telah disepakati sehingga ada keteraturan dan kewajaran.

\section{Pengaruh Budaya kerja terhadap pencapaian kinerja keuangan pemerintah}

Budaya kerja pada Badan Pusat Statistik yang telah digambarkan melalui pencapaian reformasi birokrasi memiliki nilai inti yang menjadi dasar perubahan yang akan dilakukan oleh BPS Provinsi Sumatera Utara. Nilai inti tersebut adalah PIA (Profesional, integritas dan amanah) yang harus dimiliki oleh setiap pegawai BPS Provinsi Sumatera Utara. Dalam pencapaian kinerja keuangan budaya kerja dengan nilai inti PIA tersebut sangat memiliki pengaruh. Salah satu penerapan budaya kerja dalam pencapaian kinerja keuangan adalah melalui Perumusan Renstra (rencana strategis), yang merupakan komponen dalam pencapaian kinerja keuangan bertujuan untuk menjadi pedoman dan arah proses pembaharuan yang dilakukan Badan Pusat Statistik Provinsi Sumatera Utara agar setiap aktivitas terlaksana secara lebih terstruktur, lebih terukur, dan tepat sasaran. Dalam perumusan Renstra, tidak tertutup kemungkinan adanya perubahan atau perbaikan selama jangka waktu lima tahun yang disesuaikan dengan perubahan kebutuhan dan kebijakan yang berlaku. Oleh karena itu, Renstra BPS tahun 2015-2019 perlu direviu untuk menyesuaikan dengan adanya perubahan tersebut, terutama dalam perbaikan indikator kinerja dan penjenjangan IKU (indicator kinerja utama). Reviu Renstra ini diharapkan dapat digunakan sebagai landasan dalam merumuskan, melaksanakan, dan mengevaluasi pengambilan keputusan operasional dalam pencapaian sasaran, tujuan, dan visi yang telah ditetapkan Badan Pusat Statistik dalam 5 tahun

\section{Pengaruh kompetensi terhadap Kualitas Laporan Keuangan pemerintah}


Badan Pusat Statistik telah melakukan Penataan Sistem Manajemen Sumber Daya Manusia yang telah melengkapi dokumen manajemen kepegawaian dan memebuat beberapa modul kepegawaian menjadi pelayanana berbasis elektronik juga melakukan pemetaan pegawai yang digunakan sebagai pengambilan kebijakan kepegawaian. Pelaksanaan pemetaan kepegawaian tersebut tidak terlepas dari tujuan agar kompetensi sesuai dengan bidang tugas dan fungsi yang telah ditetapkan. Berdasarkan hasil survei yang dilakukan terhadap sampel maka diperoleh informasi bahwa kompetensi berpengaruh atas kualitas laporan keuangan di Badan Pusat Statistik Provinsi Sumatera Utara. Hal ini didasarkan dengan latar belakang pendidikan dan pengalaman kerja merupakan hal yang sangat mendukung pemahaman pelaksanaan tugas dalam penyusunan laporan keuangan.

\section{Pengaruh kompetensi terhadap Kinerja Keuangan pemerintah}

Dalam menjalankan tugasnya, BPS Provinsi Sumatera Utara memiliki Sumber Daya Manusia (SDM) sebanyak 111 orang pegawai pada akhir tahun 2019. Kualitas SDM BPS Provinsi Sumatera Utara semakin membaik dilihat dari sisi pendidikan terakhir yang ditamatkan. Proporsi terbesar pendidikan tertinggi pegawai BPS Provinsi Sumatera Utara adalah D-IV/S1 yaitu sebesar 41,44 persen atau sebanyak 46 orang pegawai. Pegawai dengan pendidikan tertinggi S2 sudah cukup besar dengan proporsi 35,14 persen yaitu sebanyak 39 orang pegawai. Sementara itu, pegawai dengan pendidikan terakhir SMA dan D3 masing-masing sebesar 13,51 persen dan 9,01 persen atau sebanyak 15 orang dan 10 orang. Masalah beban kerja per pegawai kerap kali akan mempengaruhi kualitas hasil pekerjaan di setiap bagian/bidang oleh karena itu menempatkan pegawai berdasarkan komptensinya akan meningkatkan efisiensi pencapaian kinerja. Melalui survei terhadap sampel diperoleh informasi bahwa kompetensi sangat mempengaruhi pencapaian kinerja secara umum.

\section{KESIMPULAN DAN SARAN}

Berdasarkan rumusan artikel melalui studi literature dari buku laporan keuangan dan buku laporan kinerja BPS Provinsi Sumatera Utara maka dapat disimpulkan bahwa:
a. Kualitas Laporan keuangan berpengaruh terhadap kinerja keuangan
b. Kinerja keuangan berpengaruh terhadap kualitas laporan keuangan
c. Budaya Kerja berpengaruh terhadap Kualitas Laporan Keuangan
d. Budaya Kerja berpengaruh terhadap pencapaian kinerja keuangan
e. Kompetensi berpengaruh terhadap Kualitas Laporan Keuangan 
f. Kompetensi berpengaruh terhadap Kinerja Keuangan

\section{Saran}

Bersdasarkan hasil pembahasan dan Kesimpulan di atas, penulis menyadari bahwa masih banyak kekuarangan dalam penyusunan artikel ini terutama belum dilakukannya uji hipotesis terhadap hasil dan pembahasan. Penyusunan artikel ini masih terbatas hanya menggunakan data hasil kuesioner dan studi literature saja.

\section{DAFTAR PUSTAKA}

Bastian, Indra. 2019. Lingkup Akuntansi Sektor Publik Akuntansi Sektor Publik Di Indonesia.

Dylan Trotsek. 2017. “済無No Title No Title.” Journal of Chemical Information and Modeling 110(9): 1689-99.

Hariyanto, Agus. 2012. "Penggunaan Basis Akrual Dalam Akuntansi Pemerintahan Di Indonesia.” Jurnal Dharma Ekonomi 19(36): 1-11.

Hilmi, Amiruddin Zul, and Dwi Martani. 2012. “Analisis Faktor-Faktor Yang Mempengaruhi Tingkat Pengungkapan Laporan Keuangan Pemerintah Provinsi." Simposium Nasional Akuntansi XV: 1-26.

Kariyoto, Kariyoto. 2018. "PersepSi Akuntansi Sektor Publik versus Akuntansi

Pemerintahan.” Jurnal Ilmiah Bisnis dan Ekonomi Asia 11(2): 18-27.

Ke, Pertemuan, and Populasi Dan Sampel. "Pemilihan Data ( Sampel ) Penelitian." : 2-6.

Lako, Andreas. 2004. “Co Fr Fr.” 8(1): 163-73.

Pramono, Joko. 2014. “Analisis Rasio Keuangan Untuk Menilai Kinerja Keuangan Pemerintah Daerah.” Jurnal Ilmiah Among Makarti 7: 83-112.

Rizky, Harumi Puspa, and Doddy Setiawan. 2019. "Perkembangan Penelitian Akuntansi Sektor Publik Di Indonesia." Assets: Jurnal Akuntansi dan Pendidikan 8(2): 94.

Terhadap, Pelatihan, Motivasi Kerja, Serta Implikasi, and Hapzi Ali. 2016. "Kinerja Tenaga Kependidikan Di Universitas Mercu Buana Jakarta.” XXI(03): 343-59.

Upadana, I Wayan Yasa Adi Upadana et al. 2019. "Akuntansi Sektor Publik Perencanaan Dan Pengeloaan Dana Yayasan Widya Asih.” Jurnal Ilmiah Akuntansi dan Humanika 7(3): 197-208.

Wahyuni, Endang Sri, and Rosmida Rosmida. 2017. “ANALISIS PENGARUH BUDAYA ORGANISASI, LOCUS OF CONTROL TERHADAP KINERJA APARAT PEMERINTAH DAERAH DAN KEPUASAN KERJA SEBAGAI VARIABEL INTERVENING (Studi Empiris Pada Pemerintah Kabupaten Bengkalis).” Inovbiz: 
Jurnal Inovasi Bisnis 5(1): 12.

Daniel, Debby Ratna dan Supratiwi, Wiwik (2019), Sistem Informasi Manajemen. Edisi 1.

Tangerang Selatan:Universitas Terbuka.

www.bps.go.id

Standar Akuntansi Pemerintahan (SAP), Kementerian Keuangan (2010): Jakarta

Hidayah, Dini. Noer (2019). Penerapan Standar Akuntansi Pemerintahan Berbasis Akrual Pada Pemerintahan Daerah, diakses dari :

https://www.jtanzilco.com/blog/detail/1324/slug/penerapan-standar-akuntansipemerintahan-berbasis-akrual-pada-pemerintahan-daerah, tanggal 2 Oktober 2020, pukul 14.00 wib.

https://www.kemenkeu.go.id/publikasi/laporan/laporan-keuangan-pemerintah-pusat/, tanggal 3 Oktober 2020, 18.00 wib 